\title{
Impact of intestinal parasites on haematological parameters of sickle-cell anaemia patients in Nigeria
}

\author{
S.G. Ahmed ${ }^{7}$ and J. Uraka
}

$$
\begin{aligned}
& \text { أثثر الطفيليات المعوية على المتثابتات الدموية لدى مرضى فقر الدم المنجليّ في نيجيريا } \\
& \text { صغير غُمَلَ أحمد، جُودثِ عُرَكا }
\end{aligned}
$$

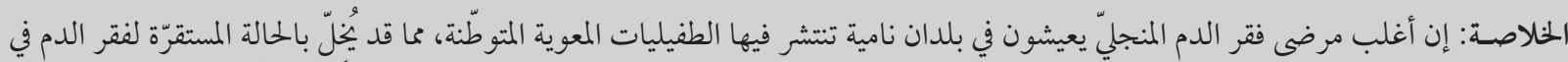

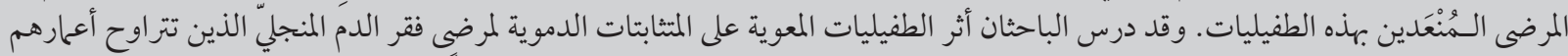

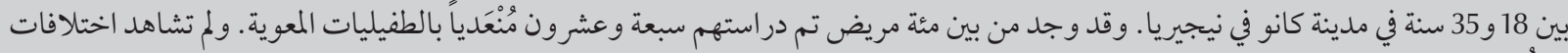

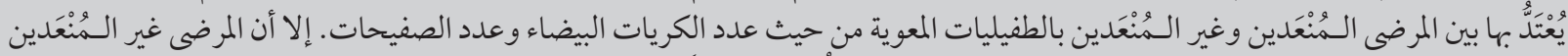

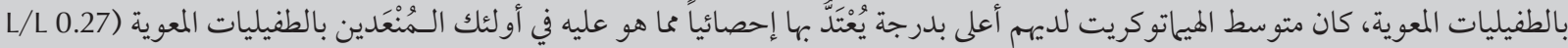

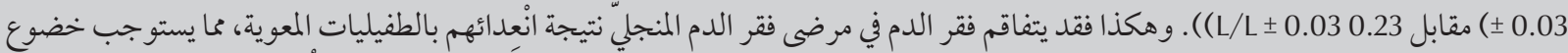

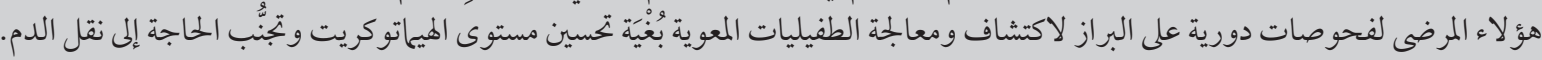

ABSTRACT The majority of patients with sickle-cell anaemia live in the underdeveloped nations where endemic parasitic diseases are prevalent and this may exacerbate the severity of steady-state anaemia in infected patients. We studied the impact of intestinal parasites on haematological parameters of sickle-cell anaemia patients aged 18-35 years in Kano, Nigeria. Of 100 patients studied, 27 were found to be infected with intestinal parasites. There were no significant differences between patients with and without parasitic infections with respect to leukocyte and platelet counts. However, patients without parasitic infections had a significantly higher mean haematocrit than patients with parasitic infections $[0.27 \mathrm{~L} / \mathrm{L}(\mathrm{SD} 0.03$ ) versus 0.23 (SD 0.03) L/L]. Anaemia in sickle-cell anaemia patients may be exacerbated by intestinal parasites, and these patients should have regular stool examinations for detection and treatment of parasitic infections in order to improve their haematocrit and avoid the risk of blood transfusion.

Effet des parasites intestinaux sur les paramètres hématologiques de patients atteints de drépanocytose au Nigéria

RÉSUMÉ La majorité des patients atteints de drépanocytose vivent dans des pays sous-développés où les maladies parasitaires endémiques sont courantes. Cette situation pourrait accentuer la sévérité de la drépanocytose chez des patients chez qui elle est stationnaire. Nous avons étudié l'impact des parasites intestinaux sur les paramètres hématologiques de patients âgés de 18 à 35 ans et souffrant de drépanocytose à Kano (Nigéria). Sur 100 patients étudiés, 27 ont reçu le diagnostic d'infestation par des parasites intestinaux. Aucune différence n'a été observée entre les patients infestés et les autres concernant la numération leucocytaire et plaquettaire. Cependant, les patients non infestés avaient un hématocrite moyen nettement supérieur à celui des patients atteints d'infection parasitaire $[0,27 \mathrm{I} / \mathrm{I}$ (E.T. 0,03) contre 0,23 I/I (E.T. 0,03)]. Chez les patients atteints de drépanocytose, I'anémie peut être accentuée par la présence de parasites intestinaux. Par conséquent, ces patients doivent bénéficier d'un examen coprologique régulier en vue de dépister et de traiter les infections parasitaires, d'améliorer leur hématocrite et de prévenir le risque de devoir procéder à une transfusion sanguine. 


\section{Introduction}

The sickle-cell gene is widespread in Africa, the Middle East and Asia and, by population movement, in the Caribbean, North America and northern Europe [1]. The frequency of sickle-cell carriers ( $\mathrm{Hb} \mathrm{AS}$ ) is up to $20 \%-25 \%$ in West Africa including Nigeria [2]. The frequency has reached high levels in these populations because the carrier state protects against malaria infection [3]. Sickle-cell anaemia (SCA) (Hb SS) affects about $2 \%$ of Nigerians [2].

SCA is associated with significant morbidity and mortality. The clinical course of SCA is characterized by variable periods of steady state that are periodically interrupted by vaso-occlusive crises resulting from polymerization of deoxygenated haemoglobin-S leading to the formation of sickled red cells $[4,5]$. Although red cell sickling is more prominent during a crisis, continuous sickling does occur at a lower rate even in steady state [4]. Sickled red cells have poor deformability and shortened life span resulting in chronic haemolytic anaemiain thesteadystate [4]. Although chronic haemolysis is the predominant factor in the etiology of anaemia in SCA, non-haemolytic factors may also contribute to the development of anaemia in such patients. Of particular concern is the fact that the overwhelming majority of SCA patients live in the underdeveloped nations of the world where endemic parasitic diseases are very prevalent and this may exacerbate the severity of steady-state anaemia in infected SCA patients. In this study in Kano, north-west Nigeria we investigate the impact of intestinal parasitic infections on the haematological parameters of SCA patients in steady state.

\section{Methods}

Stool and blood samples were collected between September 2007 and August 2008 from 100 consecutive SCA patients in steady state at the adult haematology clinic of Aminu Kano teaching hospital, Kano, north-west Nigeria. All patients were aged $18-35$ years. The diagnosis of SCA was established by positive sickling test and haemoglobin electrophoresis at a $\mathrm{pH}$ of 8.6 on cellulose acetate paper [6].

Blood samples were collected in ethylenediaminetetraacetate containers and a blood analyser (Celltac Alpha MEK 6400) was used to determine the haematological parameters including haematocrit, leukocyte count and platelet count. Blood films of each subject were examined microscopically and the leukocyte counts were corrected for the presence of nucleated red cells. Stool samples were collected in clean glass bottles containing $5 \mathrm{~mL}$ of $10 \%$ formalin-saline solution and sent to the microbiology laboratory. The samples were subjected to microscopic examination using direct and iodine preparations for the detection and identification of parasites, segments, ova, larvae or cysts [7].

The mean and standard deviation (SD) of the haematological parameters were determined for patients with and without intestinal parasitic infections. The mean values of haematological parameters for the 2 groups of patients were compared using Student t-test, and a $P$-value $<0.05$ was taken as significant. Statistical analyses were carried out using computer software SPSS, version 11.0.

\begin{tabular}{lcc}
\hline $\begin{array}{l}\text { Table 1 Frequencies of intestinal parasites among } \\
\text { with intestinal parasitic infections }\end{array}$ & \multicolumn{2}{c}{ Patients infected } \\
\hline Type of parasite & No. & $\%$ \\
& 10 & 37.0 \\
Ascaris lumbricoides & 6 & 22.2 \\
Ancylostoma duodenale & 3 & 11.1 \\
Trichuris trichiura & 2 & 7.4 \\
Strongyloides stercoralis & 7 & 25.9 \\
Entamoeba histolytica & 5 & 18.5 \\
Entamoeba coli & 2 & 7.4 \\
Giardia lamblia & & \\
\hline
\end{tabular}

\section{Results}

A total of 100 SCA patients were studied, of whom 27 were found to be infected with intestinal parasites, a prevalence of $27.0 \%$. The identified parasites included 4 helminths (Ascaris lumbricoides, Ancylostoma duodenale, Trichuris trichiura and Strongyloides stercoralis) and 3 protozoa (Entamoebahistolytica,Entamoebacoliand Giardia lamblia). Out of the 27 infected patient, 10 (37.0\%) and 17 (63.0\%) were infected with single and multiple parasites respectively. The frequencies of individual parasites among the infected patients are shown in Table 1.

The mean values of haematological parameters found among SCA patients with and without intestinal parasitic infections were compared (Table 2). Patients without intestinal parasitic infections had a mean haematocrit value of $0.27 \mathrm{~L} / \mathrm{L}$, which was significantly higher than the value of $0.23 \mathrm{~L} / \mathrm{L}$ in patients with infections $(P<0.05)$. Patients without intestinal parasitic infections had a mean leukocyte count of $11 \times 10^{9} / \mathrm{L}$ and a mean platelet count of $453 \times 10^{9} / \mathrm{L}$ and these did not differ significantly from the counts of $12 \times 10^{9} / \mathrm{L}$ and $462 \times 10^{9} / \mathrm{L}$ respectively in patients with infection.

\section{Discussion}

The prevalence of intestinal parasites in Nigeria is very high in children, with reported rates consistently over 50\% in 


\begin{tabular}{|c|c|c|c|c|}
\hline \multirow[t]{2}{*}{ Parameter } & \multirow{2}{*}{$\begin{array}{l}\text { Without infection } \\
\qquad(\boldsymbol{n}=73) \\
\text { Mean (SD) }\end{array}$} & \multirow{2}{*}{$\begin{array}{l}\text { With infection } \\
\qquad(n=27) \\
\text { Mean (SD) }\end{array}$} & \multicolumn{2}{|c|}{ Statistics } \\
\hline & & & $t$-value & $P$-value \\
\hline Haematocrit (L/L) & $0.27(0.03)$ & $0.23(0.03)^{*}$ & 5.920 & $<0.001$ \\
\hline Leukocyte count $\left(\times 10^{9} / \mathrm{L}\right)$ & $11.0(2.3)$ & $12.0(2.5)$ & 1.885 & 0.0623 \\
\hline Platelet count $\left(\times 10^{9} / \mathrm{L}\right)$ & $453(45)$ & $462(48)$ & 0.872 & 0.3853 \\
\hline
\end{tabular}

$S D=$ standard deviation.

many communities [8]. However, the prevalence has been shown to decrease withincreasing age andisgenerally lower in older children and adults [9]. Hence, the relatively low prevalence of $27.0 \%$ seen among our patients was consistent with their ages, as all of them were young adults aged between 18 and 35 years. The pattern of infections with respect to the frequencies of individual parasites found in our patients is very similar to the trend previously reported in the general Nigerian population [9]. This pattern revealed that the infections were predominantly due to soil-transmitted helminths and protozoans, which are strongly associated with poverty and poor personal and environmental hygiene [10].

The haematological parameters of our patients revealed comparatively similar high mean leukocyte counts in SCA patients with and without parasitic infections. This is consistent with earlier studies showing that leukocytosis is a common feature of SCA even in steady state. This was thought to be due to redistribution of granulocytes from the marginal to the circulating pool [11]. Furthermore, the mean platelet counts were high but similar in both patient groups. The finding of high platelet counts in our patients is consistent with earlier studies, which showed that thrombocytosis was common in SCA and was attributed to the background haemolytic anaemia and the autosplenectomy associated with the disease [11]. However, the mean haematocrit level of our patients without parasitic infections was significantly higher than the level among patients with parasitic infections. Hence, SCA patients that were infected with intestinal parasites had more severe steadystate anaemia in comparison with their counterparts without intestinal parasitic infections.

This finding reveals a possible association between intestinal parasitic infection and the severity of anaemia in SCA patients. Intestinal parasites are strongly associated with the development of anaemia as they cause malabsorption, nutritional deficiencies and gastrointestinal blood loss [10]. Therefore, the more severe anaemia found in SCA patients with intestinal parasites was likely a result of the combined effect of haemolysis due to sickle-cell disease and malabsorption, nutrient deficiencies and gastrointestinal blood loss due to infection with intestinal parasites. It is therefore important that SCA patients who live in the tropics should have regular periodic stool microscopic examination in order to detect and treat any parasitic infections. This will significantly reduce the severity of steady-state anaemia and avoid the risk of blood transfusion in such patients. Furthermore, physicians involved in managing SCA patients in the tropics must counsel such patients on basic sanitary practices such as washing fresh vegetables and fruits before consumption, proper cooking of meat before eating, boiling stream water before drinking, proper disposal of faecal matter and avoidance of walking or farming bare-foot, all of which are important to safeguard against the acquisition of intestinal parasites $[12,13]$.

\section{Conclusion}

Steady-state anaemia in patients with SCA is exacerbated by infection with intestinal parasites. Hence, SCA patients should have regular periodic stool examinations for early detection and treatment of intestinal parasites in order to raise their haematocrit, improve their quality of life and avoid the risk of transfusion.

\section{References}

1. Flint J et al. The population genetics of the haemoglobinopathies. Bailliere's Clinical Haematology, 1993, 6:215-222.

2. Akinkugbe OO. Sickle cell disease. In: Akinkugbe OO, ed. Non-communicable diseases in Nigeria, 1st ed. Lagos, Federal Ministry of Health, 1992: 36-48.

3. Hood AT. Protection against lethal malaria in transgenic mice expressing sickle cell haemoglobin. Blood, 1996, 87:16001603.
4. Kaul DK, Fabry ME, Nagel RI. The pathophysiology of vascular obstruction in the sickle cell syndromes. Blood Reviews, 1996, 10:29-44.

5. Davies SC, Oni L. Management of sickle cell disease. British Medical Journal, 1997, 315:656-660.

6. Dacie JV et al. Investigation of abnormal haemoglobins and thalassaemia. In: Dacie JV, Lewis SM, eds. Practical haematology, 7th ed. London, Churchill Livingstone, 1991:227-257. 
7. Cheesbroug M. Medical laboratory manual for tropical countries, 2nd ed. London, Butterworth, 1987.

8. Ijagbone IF, Olagunju TF. Intestinal helminth parasites in school children in Iragbiji, Boripe local government area, Osun state, Nigeria. African Journal of Biomedical Research, 2006, 9:63-65.

9. Agi PI. Pattern of infection of intestinal parasites in Sagbama community of the Niger Delta, Nigeria. West African Journal of Medicine, 1995, 14:39-42.

10. Ejezie GC, Emeribe AO, Igwe MA. Human ecology and parasitic infections in Nigeria: relationship between parasitic infec- tions and anaemia. Journal of Medical Laboratory Science, 1993, 3:22-26.

11. Ahmed SG, Ibrahim UA, Hassan AW. Haematological Parameters of Sickle Cell Anaemia Patients with and without priapism. Annals of Saudi Medicine, 2006, 26:439-443.

12. Damen JG et al. Parasitic contamination of vegetables in Jos, Nigeria. Annals of African Medicine, 2007, 6:115-118.

13. Adeyeba OA, Essiet U. Prevalence of helminth and protozoan infections among a religious sect that walk barefooted in Iseyin, Nigeria. Nigerian Journal of Parasitology, 2001, 22:85-94.

\section{Haemoglobin disorders}

It is estimated that each year over 300000 babies are born worldwide with severe forms of the haemoglobin disorders, sickle-cell disease and thalassaemia, the majority in low and middle income countries. The most cost-effective strategy for reducing the burden of haemoglobin disorders is to complement disease management with prevention programmes.

Sickle-cell disease can be managed by simple procedures including: high fluid intake; healthy diet; folic acid supplementation; pain medication; vaccination and antibiotics for the prevention and treatment of infections; a number of other therapeutic measures. Genetic counselling can informs couples carrying the trait of the risks that the condition may be passed along to their children, the treatment needed, if affected by a haemoglobin disorder, and the possible options for the couple.

The governing bodies of WHO have adopted two resolutions on haemoglobin disorders. The resolution on sickle-cell disease from the 59th World Health Assembly in May 2006 and the resolution on thalassaemia from the 118th meeting of the WHO Executive Board call upon affected countries and the Secretariat of WHO to strengthen their response to these conditions. In addition, a resolution on the prevention and management of birth defects, including sickle-cell disease and thalassaemia, was adopted by the 63rd World Health Assembly in May 2010.

Specifically, WHO will: increase awareness of the international community of the global burden of these disorders; promote equitable access to health services; provide technical support to countries for the prevention and management of these disorders; and promote and support research to improve quality of life for those affected.

Source: WHO Fact sheet, No. 308

January 2011 